\title{
The Roles of Teacher and Students via Blended Problem-Based Learning: Improving Students' Mastery of Three Representation Levels of Chemistry Mohd Mokhzani Ibrahim ${ }^{*}$, Khairul Azhar Jamaludin ${ }^{2}$
}

\author{
${ }^{1}$ Department of Chemistry, Universiti Pendidikan Sultan Idris, Malaysia \\ ${ }^{2}$ Department of Curriculum and Instructional Technology, Universiti Malaya, Malaysia \\ *Corresponding author: mokhzani@fsmt.upsi.edu.my \\ DOI: https://doi.org/10.37134/ejsmt.vol6.2.2.2019
}

Received: 13 August 2019; Accepted: 11 December 2019; Published: 13 December 2019

\begin{abstract}
The current practice in teaching Chemistry subject is found to be teacher-centered where teachers engage actively in transmitting knowledge while students act as passive recipients of knowledge. This might affect students' mastery in learning three representation levels of Chemistry (macroscopic, microscopic and symbolic). As a result, students tend to form a non-scientific understanding and develop an alternative concept. The shift to Blended Problem-based Learning (BPBL) is therefore potential to help overcome this problem. Thus, this study is aimed at investigating the roles of teacher and students in overcoming the formation of alternative concepts for three representation levels of Chemistry in BPBL. This study applies a case study research design. Two teachers and 20 students from two different Fully Residential Schools are selected using purposive sampling technique. Data are collected through observations and students' documents, and analysed thematically. Overall, the findings of this study shows that teacher acts as mediator in giving immediate feedbacks and corrections on students' alternative concept while students act as evaluator in analyzing and evaluating other group's answers. As a conclusion, the implementation of BPBL is found beneficial to overcome the formation of alternative concept and thus helps to improve students' mastery of three representation levels of Chemistry.
\end{abstract}

Keywords: Three representation levels of Chemistry, Alternative concept, Blended Problem-based Learning

\section{INTRODUCTION}

Poor mastery of three representation levels of Chemistry has resulted in poor achievement in this subject. Macroscopic, microscopic and symbolic are related to one another (refer Figure 1) and failure to understand this complex relationship will lead to confusion and misunderstanding [1,2]. The macroscopic representation level refers to the phenomenon that can be touched, viewed and smelt, such as seeing the colour changes as the result of chemical reaction [3,4]. The microscopic representation level is related to atomic matter theory, which is in relation to atoms, molecules and ions $[5,6]$. The symbolic representation level includes chemical equations and formulas representing microscopic representations [7,5].

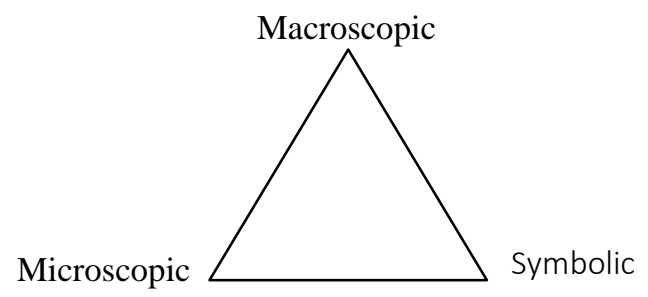

Figure 1: Three Representation Level of Chemistry 
Studies on this issue have discovered that the lack of understanding of this concept is rooted from poor ability of students in connecting these three representation levels $[8,9,10]$. As a result, students tend to form an alternative concept [6], which is misleading. Students tend to rely on this concept that is part of their existing knowledge, and thus limiting their ability to master the correct concepts [11, 12]. As viewed by [13] in his Cognitivist Theory, a new knowledge can only be constructed from the existing knowledge. Therefore, it is pivotal to ensure students acquire a correct understanding as the foundation to develop their new knowledge.

In addition, providing students with opportunities to share their existing knowledge with each other in discussing a particular problem [14], such as in Problem-Based Learning (PBL) is very beneficial $[15,16,17]$. This is because, collaborative learning in PBL allows students to solve problems efficiently [18], and is proven to be beneficial in correcting students' alternative concept $[19,20]$.

Unfortunately, these scenarios do not occur in the current teaching and learning in schools where students are mostly acting in a passive manner; depending on the teacher's instruction and guidance $[21,20]$ including high achiever students in fully residential schools (Sekolah Berasrama Penuh) $[21,20]$. Hence, there is a need to transform a teacher-centered teaching approach to PBL. This is because, PBL is highly potential to help address the issue of alternative concept formation among students in learning three representation level of Chemistry [19, 22].

Besides, in line with the 21 st century learning, technology integration through a combination of face-to-face and online learning modes known as the Blended PBL (BPBL) approach, is potential to enhance the existing PBL learning process $[23,24]$. This is because the combination of face-to-face and online learning mode helps to strengthen the benefits of existing PBL and at the same time overcome the weaknesses in both learning modes $[23,25,26]$.

Realizing its potential in overcoming the above issue, it is worth to further investigate roles of teacher and students in a students-centred learning of BPBL. The findings are pivotal to further highlight BPBL strengths in developing mastery of the three representation levels of Chemistry concept.

\section{RESEARCH OBJECTIVE AND QUESTION}

The current study aims to investigate the roles of teacher and students in overcoming alternative concept formation in three representation levels of Chemistry via BPBL. Hence, the research question is: What and how are the roles of teachers and students in overcoming the formation of alternative concept of three representation level of Chemistry concept via Blended Problem-Based Learning?

\section{METHODOLOGY}

This study applied a case study research design as proposed by [27]. He further elaborated that this design is relevant to further explore and understand a unique case related to an issue. Relevant to the aim of the current study, the selected schools are unique as it implements BPBL compared to other fully residential schools that practice teacher-centred classroom. The selection of these schools is aligned with the aim of the Ministry of Education of Malaysia to upgrade fully residential schools as the bench mark and example to all schools in Malaysia [28].

For this study, two teachers and 20 students from two fully residential schools were selected using purposive random sampling technique. This sampling technique is selected as the initial selected schools have met the criteria for this study, which: i) are relevant to be a model school for 
excellence, and ii) have Form Four students who study Chemistry subject. Next, a random draw technique as suggested by Chua (2010) has been utilized to pick two schools from 69 possible schools that have met the criteria.

Data was collected from two instruments: (i) Data from observation (direct and online forums discussion), and (ii) student documents (FILA Chart). Data was analysed thematically as suggested by [29], as shown in Figure 2.

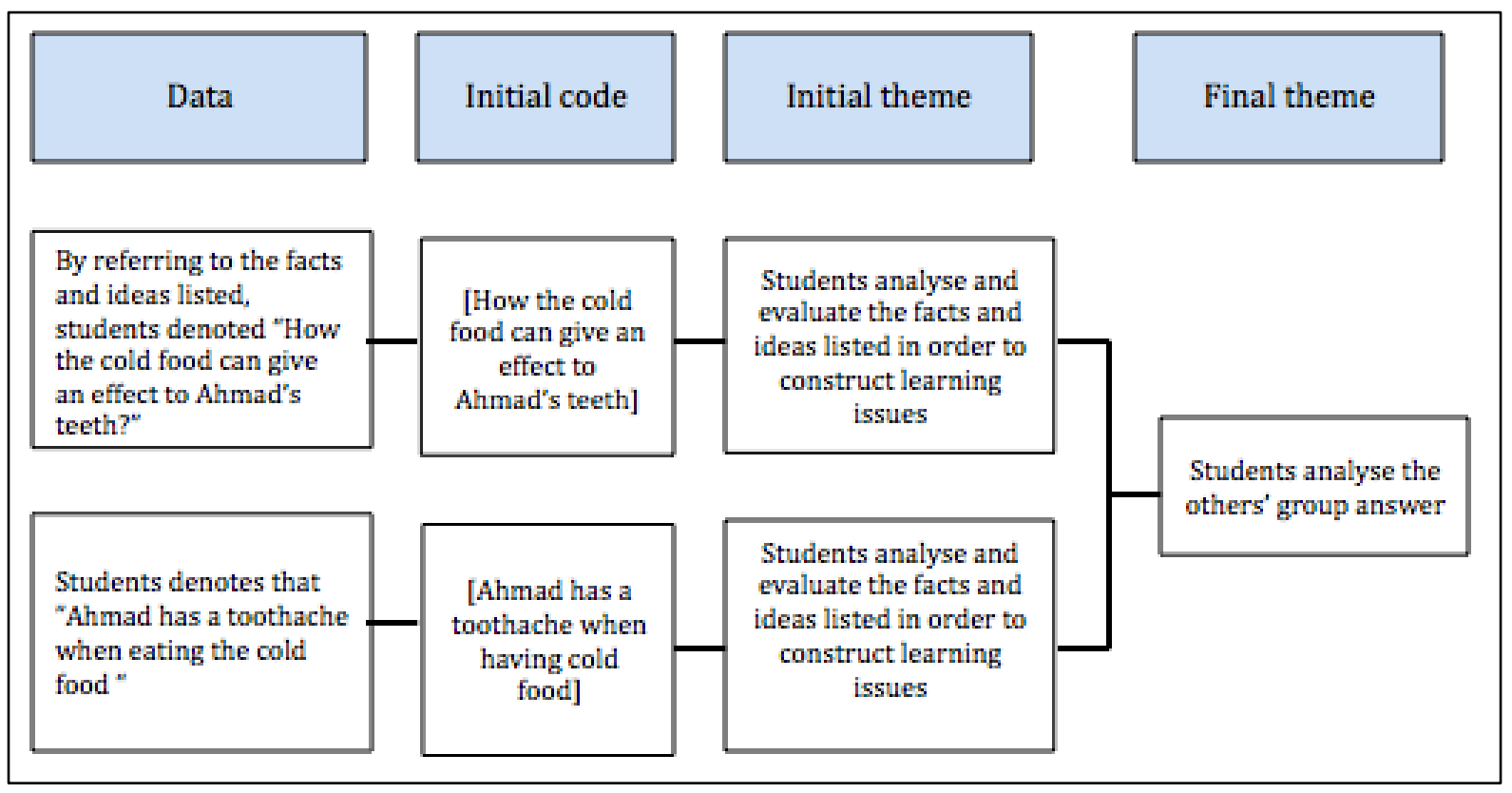

Figure 2: Example of thematic data analysis

Figure 2 shows an example of thematic data analysis implemented in this research. There are four stages of data analysis which are: (i) data, (ii) initial code, (iii) initial theme, and (iv) final theme. In step i, the data from all instruments was transcript. Then, in step ii, the transcript data was read few times in order to classify them into groups known as 'initial code'. Next, in step iii, all the initial codes, which have the same pattern, will be grouped in the same 'initial theme'. Lastly, in step iv, all the initial codes were checked again. Those, which have the same pattern, will be combined together as the new theme known as the 'final theme'.

In this study, the BPBL learning process was implemented based on BPBL Model proposed by [22] as presented in Figure 3. 


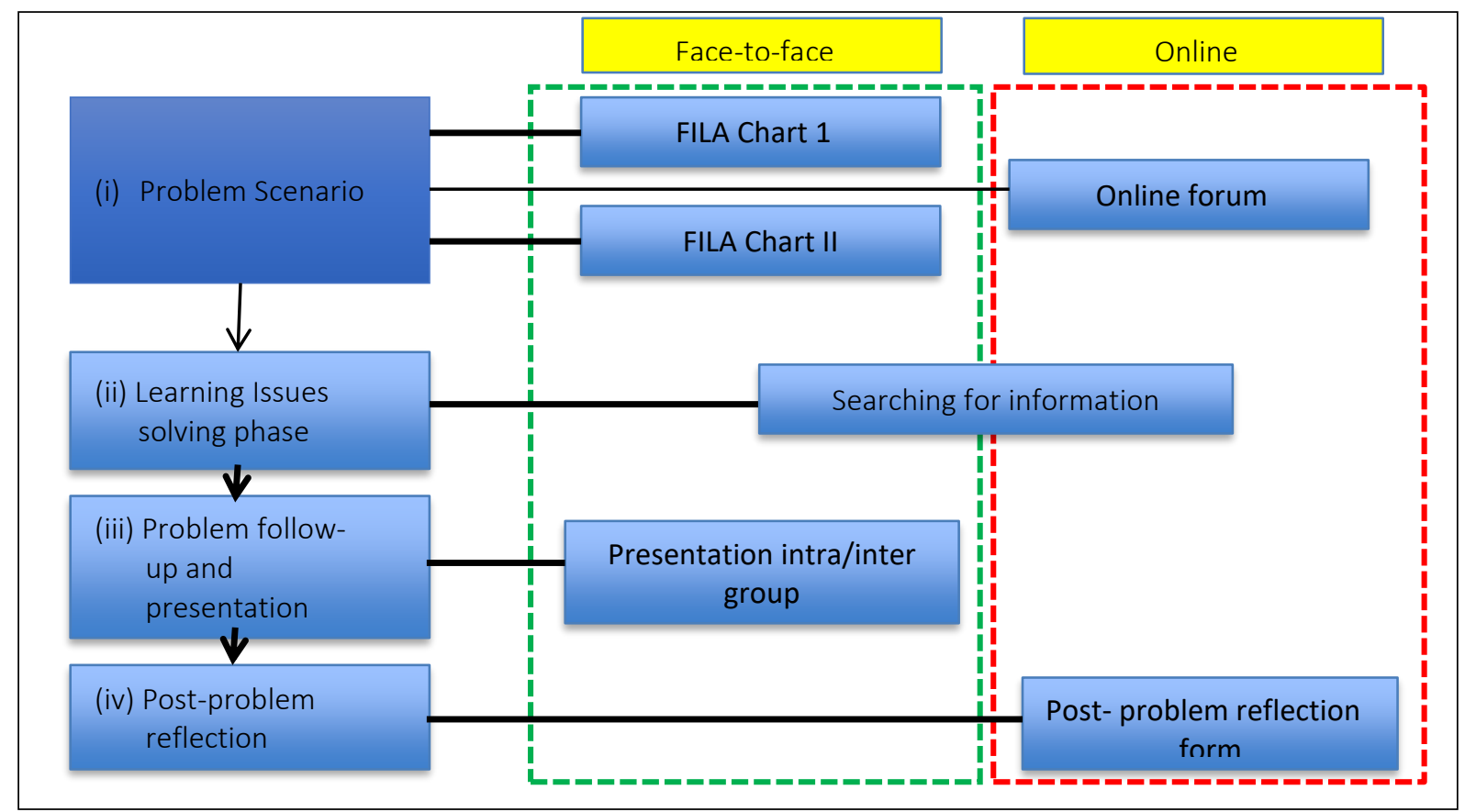

Figure 3: Blended PBL Model adopted from Mohd Mokhzani et al., (2016)

According to [22], there are four steps in BPBL model: (i) problem scenario, (ii) learning issues solving phase, (iii) problem follow-up and presentation, and (iv) post-problem reflection. Step iii was done via face-to-face mode while step i, ii and iv were done both in face-to-face and online mode. But in this paper, only step i (problem scenario) will be discussed into details. This is because alternative concept formation typically occurred in this phase, and failure to address this issue will affect the overall learning process [19]. Step i, iii and iv were implemented during class session while step ii was implemented both during class and after class. For the purpose of implementation, the BPBL environment has developed in the online platform as presented in Figure 4.

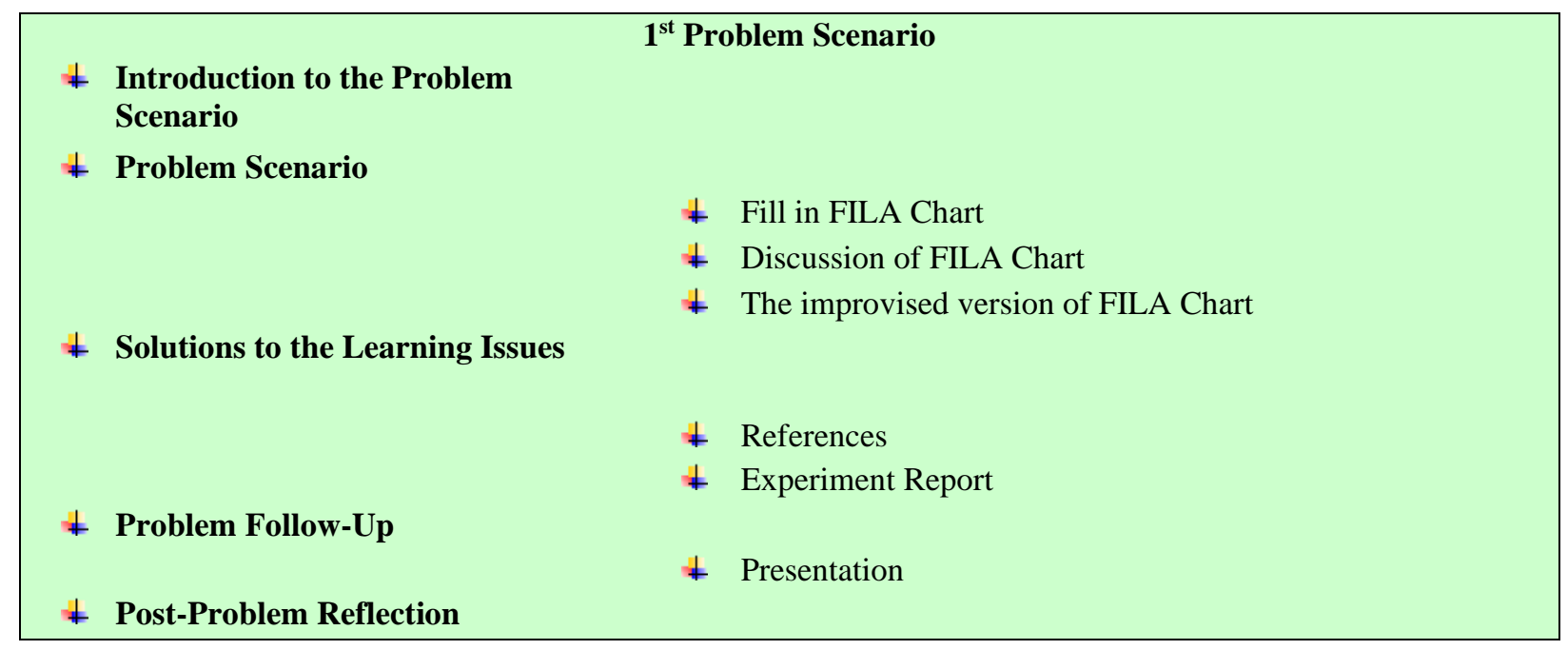

Figure 4: The Blended Problem-Based Learning Environment 
Figure 4 shows an example of the BPBL learning environment which has been developed in the Modular Object-Oriented Dynamic Learning Environment, also known as MOODLE [30]. Online forum discussion and hyperlink are some features of MOODLE which potentially enhance students' social interactions [31, 32], and thus, have been applied in this research. Students were divided into groups of five. Each group needed to appoint a leader, a secretary, observers and scribes. Each position has its own task as illustrated in Table 1. Then, the learning process began with a problem scenario given by the teacher. The problem scenario is about a conversation between a school boy who was having a toothache and a dentist at a clinic (refer Appendix 1). The problem covers the acid and base chapter, which is included in the form four chemistry syllabus designed by Curriculum Development Centre Malaysia (2012).

Table 1: The Task to Each Position

\begin{tabular}{|l|l|}
\hline \multicolumn{1}{|c|}{ Position } & \multicolumn{1}{c|}{ Task } \\
\hline Leader & Lead the discussion session \\
\hline Secreatary & Post (upload) the FILA Chart to the online forum \\
\hline Observer & Actively enggage in the discussion session \\
\hline Scribe & Write down all the main points during discussion session. \\
\hline
\end{tabular}

In helping students to analyse the problem, a FILA chart (Facts, Ideas, Learning Issues and Actions) which adapted from [33] as in Figure 5, was given. Here, the three representation levels of Chemistry (macroscopic, microscopic and symbolic) were emphasized in the 'Idea' column. The explanation for the FILA chart is given in Table 2.

\begin{tabular}{|l|l|l|l|l|l|}
\hline \multirow{2}{*}{ Facts } & \multicolumn{3}{|c|}{ Ideas } & Learning Issues & Actions \\
\cline { 2 - 4 } & Macroscopic & Microscopic & Symbolic & & \\
\hline & & & & & \\
\hline
\end{tabular}

Figure 5: FILA Chart adapted from Tan Yin Peen and Mohammad Yusof (2013)

Table 2: Explanation of the FILA Chart

\begin{tabular}{|l|l|}
\hline \multicolumn{1}{|c|}{ Coloumn } & \multicolumn{1}{c|}{ Explanation } \\
\hline Facts & Information extracted from the problem scenario. \\
\hline Macroscopic Ideas & Any ideas about the problem based on facts identified. \\
\hline Microscopic Ideas & Theory at particulate level \\
\hline Symbolic Ideas & Related to any symbols, for example chemical equation. \\
\hline Learning Issues & Things that need to be found to solve the problem. \\
\hline Action & $\begin{array}{l}\text { Ways/Methods/ Activities to be taken in order to get the answer for learning } \\
\text { issues which has discovered earlier. }\end{array}$ \\
\hline
\end{tabular}

In groups, students discussed with each other to complete the FILA chart. Next, the secretary of each group needed to upload the FILA chart in the online platform. During the online forum session, each group must give feedback on others' FILA chart. Students reviewed with their group members on their FILA charts if any amendment needed, after the online discussion session ended. Next, the secretary of each group uploaded the revised FILA chart on the online platform again. Overall, BPBL took six weeks to be implemented as presented in Table 3. 
Table 3: The Duration of the Implementation of BPBL

\begin{tabular}{|c|c|c|}
\hline Learning Phase & Learning activity & Duration \\
\hline \multirow{4}{*}{$\begin{array}{l}\text { Problem } \\
\text { scenario }\end{array}$} & - Assigning the task between group member & \multirow[t]{4}{*}{ Week 1 and week 2} \\
\hline & - FILA chart (1) & \\
\hline & - Discussion forum & \\
\hline & - FILA chart (2) & \\
\hline $\begin{array}{l}\text { Learning issues } \\
\text { solving phase }\end{array}$ & $\begin{array}{l}\text { - Discussion in group in order to solve the } \\
\text { learning issues }\end{array}$ & Week 3 and week 4 \\
\hline $\begin{array}{c}\text { Problem follow- } \\
\text { up and } \\
\text { presentation }\end{array}$ & - Intra and inter group presentation & Week 5 \\
\hline \multirow[t]{2}{*}{$\begin{array}{l}\text { Post problem } \\
\text { reflection }\end{array}$} & $\begin{array}{l}\text { - Student complete the post problem } \\
\text { reflection form. }\end{array}$ & \multirow[t]{2}{*}{ Week 6} \\
\hline & - Interview & \\
\hline
\end{tabular}

\section{RESULTS AND DISCUSSIONS}

In this study, after the implementation of BPBL, it is found that the teachers were able to help students overcome the formation of alternative concept during learning sessions. Students, on the other hand, were able to work collaboratively and independently in developing an accurate mastery of three representation levels of Chemistry during the lessons. As aforementioned, the students will first discuss among their group members to complete the given FILA Chart (1) and post it into the online forum as shown in Figure 6.

\begin{tabular}{|c|c|c|c|c|c|}
\hline \multirow[t]{2}{*}{ Facts } & \multicolumn{3}{|c|}{ Ideas } & \multirow{2}{*}{$\begin{array}{l}\text { Learning } \\
\text { lssues }\end{array}$} & \multirow[t]{2}{*}{ Actions } \\
\hline & Macroscop̧ic & Mierossoopic & Symbolic & & \\
\hline $\begin{array}{l}\text { - Ahmad has } \\
\text { toothache when } \\
\text { cating cold food } \\
\text { - Ahmad lowe to eat } \\
\text { pickle } \\
\text { - Ahmod always } \\
\text { drink pepsi } \\
\text { - Ahmad always use } \\
\text { different tootpaste } \\
\text { brand. }\end{array}$ & $\begin{array}{l}\text { - Pepsi contains } \\
\text { an high maount } \\
\text { of sugar } \\
\text { - Pepsi is an } \\
\text { isotonik drinks } \\
\text { - Teeth also } \\
\text { known as } \\
\text { calcium } \\
\text { carbonate }\end{array}$ & $\begin{array}{l}\text { Sugar acid corrodes } \\
\text { Ahmad's teeth and } \\
\text { feauses him to bave } \\
\text { sensitive teeth. }\end{array}$ & $\begin{array}{l}\text { - Calcium, } \mathrm{Ca} \\
\text { - Carbonate, } \\
\mathrm{CO}_{3} \\
\text { - Carbon, C }\end{array}$ & $\begin{array}{l}\text { How cold } \\
\text { food can } \\
\text { give an } \\
\text { effect to } \\
\text { Ahmad's } \\
\text { teeth? }\end{array}$ & $\begin{array}{l}\text { - Discussion } \\
\text { with the } \\
\text { groups' } \\
\text { members }\end{array}$ \\
\hline & & & & & $\begin{array}{l}\text { Alternative } \\
\text { concept }\end{array}$ \\
\hline
\end{tabular}

Figure 6: Students' alternative concept on microscopic level in FILA Chart (1) 
Figure 6 shows an example of the alternative concept on microscopic level done by student in FILA Chart 1. In the third column at microscopic idea, students have given an answer as 'Sugar acid corrodes Ahmad's teeth and causes him to have sensitive teeth'. It is found that, the teacher stimulated students to justify microscopic ideas that led them to identify alternative concept (the use of incorrect term, sugar acid) as the example in Figure 7.

Student A:

Sugar Acid? Can you explain about it?

Teacher:

I am also interested to know more about sugar acid. Can anyone from your group explain about it in detail?

Student B2:

Sugar acid, what we meant is actually acetic acid, $\mathrm{CH}_{3} \mathrm{COOH}$

Student A:

Can acetic acid be called as sugar acid?

Student B2:

For me, both of them are the same.

Figure 7: Example of students' alternative concept for 'sugar acid' on microscopic level.

Based on the above example, the discussion started when Student A asked explanation on 'sugar acid' term. Instead of providing answer, the teacher prompted a question: "Can anyone from your group explain about it in detail?". Clearly, the prompted question functions as thought-provoking question that encourages students to justify their statement through discussion. This is in line with what has been highlighted by [34], as an advantage to use this approach in encouraging students' active participation and reasoning in learning.

Students are also responsible for analyzing and evaluating other group's answer on Fact, Idea, Learning Issue and Action (FILA) charts in order to gain justification regarding ideas on microscopic level. This discussion begun when Student A asked for further explanation on the term 'sugar acid' used by his group ("Can acetic acid be called as sugar acid?). However, Student B2 simply concluded that both terms were correct ("For me, both of them are the same"). This is an example of formation of alternative concept. [35, 36], justified that this situation happened due to informal learning that occurred outside classroom, and thus affecting how these students form their understanding.

In addition, the formation of alternative concepts on symbolic level among students is also shown in Figure 8 below. 


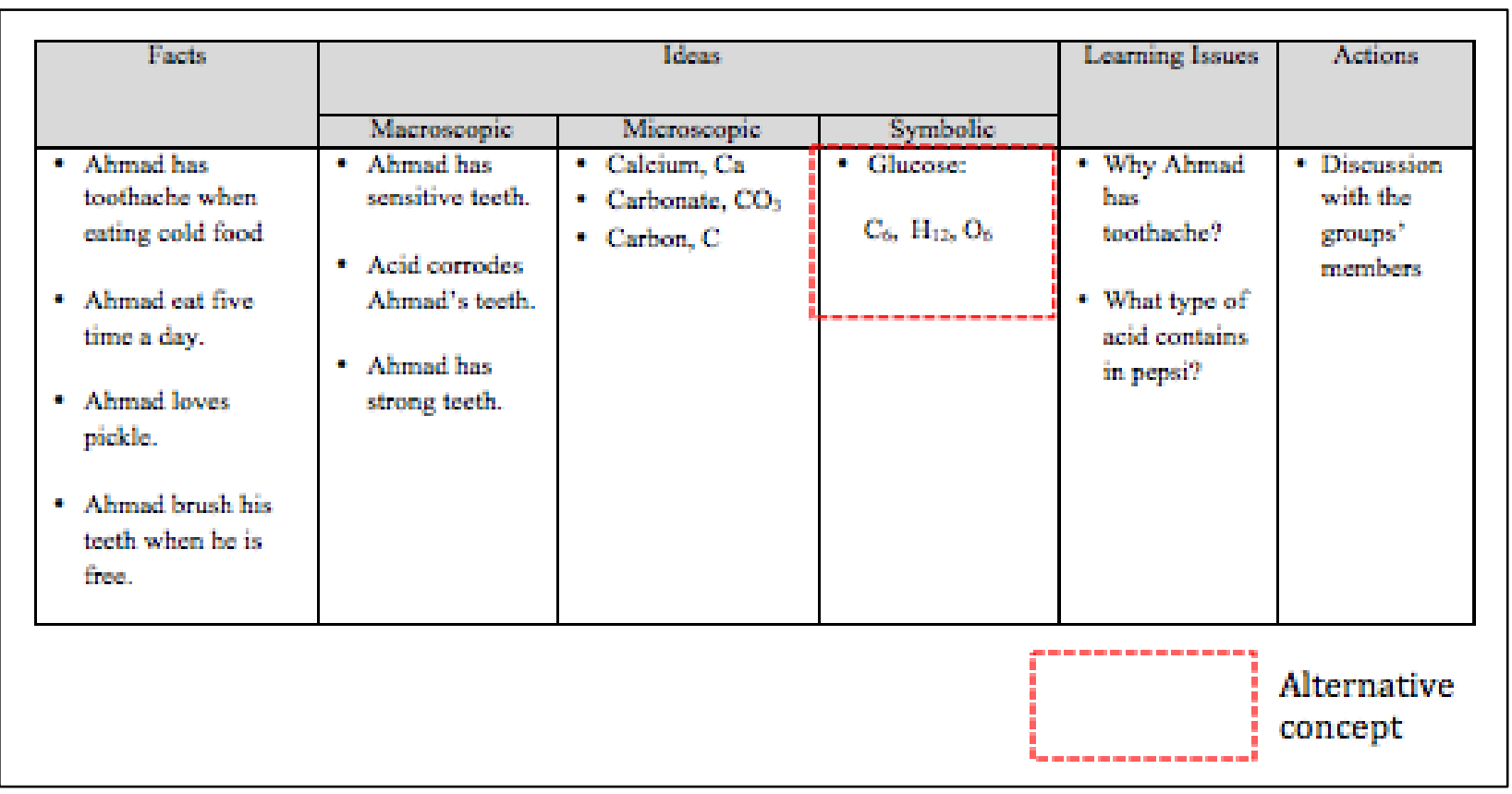

Figure 8: Students' alternative concept on symbolic level through FILA Chart (1)

Figure 8 shows an example of the FILA chart, which has been uploaded by students into online forum discussion. In the fourth column at symbolic idea, students have given answer as 'Glucose: $C_{6}, H_{12}$, $O_{6}$ '. This shows that the student assumed glucose $\left(\mathrm{C}_{6}, \mathrm{H}_{12}, \mathrm{O}_{6}\right)$ can be separated simply into its compositions. Again, the teacher stimulated students to identify the alterantive concept by posing question as the following example taken from online forum discussion (Figure 9).

Student A:

Why the symbol of hydrogen is $\mathrm{H}_{12}$ ?

Student A1:

$\mathrm{H}_{12}$ is the fraction of glucose $\left(\mathrm{C}_{6} \mathrm{H}_{12} \mathrm{O}_{6}\right)$

Teacher:

Can you simply separate an element from its compound?

Student A1:

Yes, by electrochemistry and heating process.

Figure 9: Example of students' alternative concept on separation of element from its compound

Based on Figure 9, initially, Student A analyzed and evaluated the other group's answer by asking 'Why the symbol of hydrogen is $\mathrm{H}_{12}$ ?'. Student A1 was able to justify by explaining that: " $\mathrm{H}_{12}$ is a fraction of glucose $\left(\mathrm{C}_{6} \mathrm{H}_{12} \mathrm{O}_{6}\right)$ ". The teacher prompted another question: "Can you simply separate an element from its compound?". The reason to this question was to direct the student to rethink on the answer given, which was identified as an alternative concept. Student A1 replied that it is possible to do so: "Yes, through electrochemistry and heating process". Even though the student's response is 
categorized as an alternative concept for definition of chemical compounds (under chemical bonding topic), the teacher's question was able to direct students to rethink and provide justification to reflect their understanding. It is undeniable that students' understanding often based on alternative concepts especially for the concept of chemical bonding [8,37] but later after undergone the BPBL learning, students were able to overcome this problem.

After discussing in online forum discussion, students analyzed and re-evaluated the facts, ideas and issues of learning in carrying out the reflection process. This reflection process allowed students to define ideas and learning issues that have been set before. Students also detailed microscopic ideas by not listing ideas based on alternative concepts. For example, students no longer used the term 'sugar acid' in the FILA chart as preseneted in Figure 10.

\begin{tabular}{|c|c|c|c|c|c|}
\hline \multirow[t]{2}{*}{ Facts } & \multicolumn{3}{|c|}{ Ideas } & \multirow{2}{*}{$\begin{array}{l}\text { Learning } \\
\text { lssues }\end{array}$} & \multirow[t]{2}{*}{ Actions } \\
\hline & Macroscopic & Microscopic & Symbolic & & \\
\hline $\begin{array}{l}\text { - Ahmad has } \\
\text { toothache when } \\
\text { eating cold food } \\
\text { - Ahmad love to eat } \\
\text { pickle } \\
\text { - Ahmad always } \\
\text { drink pepsi } \\
\text { - Ahmod always use } \\
\text { different tootpaste } \\
\text { brand. }\end{array}$ & $\begin{array}{l}\text { - Pepsi contains } \\
\text { an high maount } \\
\text { of sugar } \\
\text { - Pepsi is an } \\
\text { isotonik drirks } \\
\text { - Teeth also } \\
\text { known as } \\
\text { calcium } \\
\text { carbonate }\end{array}$ & $\begin{array}{l}\text { - Calcium, } \mathrm{Ca} \\
\text { - Carbonate, } \mathrm{CO}_{3} \\
\text { - Carbon, C }\end{array}$ & $\begin{array}{l}\text { - Glucose } \\
\left(\mathrm{C}_{6} \mathrm{H}_{12} \mathrm{O}_{6}\right)\end{array}$ & $\begin{array}{l}\text { - How cold } \\
\text { food can } \\
\text { give an } \\
\text { effect to } \\
\text { Ahmad's } \\
\text { teeth? }\end{array}$ & $\begin{array}{l}\text { - Discussion } \\
\text { with the } \\
\text { groups' } \\
\text { members }\end{array}$ \\
\hline
\end{tabular}

Figure 10: The correction of alternative concept at microscopic level through FILA Chart (2)

Figure 10 clearly shown that students have changed the alternative concept at microscopic level ('sugar acid') to a more accurate answer which was Calcium (Ca), Carbonate $\left(\mathrm{CO}_{3}\right)$ and Carbon (C) in FILA Chart 2. Students also changed the alternative concept at symbolic level as shown in Figure 11.

\begin{tabular}{|c|c|c|c|c|c|}
\hline \multirow[t]{2}{*}{ Facts } & \multicolumn{3}{|c|}{ Ideas } & \multirow[t]{2}{*}{ Learning Issues } & \multirow[t]{2}{*}{ Actions } \\
\hline & Macroscopic & Microscopic & Symbolic & & \\
\hline $\begin{array}{l}\text { - Ahmad has } \\
\text { toothache when } \\
\text { eating cold food } \\
\text { - Ahmad eat five } \\
\text { time a day. } \\
\text { - Ahmod loves } \\
\text { pickle. } \\
\text { - Ahmod brush his } \\
\text { teeth when be is } \\
\text { froe. }\end{array}$ & $\begin{array}{l}\text { - Ahmad has } \\
\text { sensitive teeth. } \\
\text { - Acid corrodes } \\
\text { Ahmad's teeth. } \\
\text { - Ahmad has } \\
\text { strong teeth. }\end{array}$ & $\begin{array}{l}\text { - Calcium, } \mathrm{Ca} \\
\text { - Carbonate, } \mathrm{CO}_{3} \\
\text { - Carbon, C }\end{array}$ & $\begin{array}{l}\text { - Glucose: } \\
\mathrm{C}_{6} \mathrm{H}_{12} \mathrm{O}_{6}\end{array}$ & $\begin{array}{l}\text { - Why Ahmad } \\
\text { has } \\
\text { toothache? } \\
\text { - What type of } \\
\text { acid contains } \\
\text { in pepsi? }\end{array}$ & $\begin{array}{l}\text { - Discussion } \\
\text { with the } \\
\text { groups' } \\
\text { members }\end{array}$ \\
\hline
\end{tabular}

Figure 11: The correction of alternative concept at symbolic level through FILA Chart (2) 
Figure 11 shows the correction that has been done by the students at symbolic level in FILA Chart (2). Students have corrected their alternative concept by giving a more accurate answer which was the correct molecular formula of glucose $\left(\mathrm{C}_{6} \mathrm{H}_{12} \mathrm{O}_{6}\right)$.

During the face-to-face monitoring by teachers, the teachers initially failed to identify this alternative concept during the discussion. However, the integration of online learning, which was forum discussion, has allowed corrections for the alternative concepts. Clearly, the integration of online platform offers an advantage over existing PBL, and at the same time enhances the roles of teacher in monitoring students' learning. This is in line with the findings in $[23,38]$ study, where they appointed that online learning can enhance teacher roles in monitoring students throughout the learning process. It is very important to identify students' formation of alternative concept because it will lead to poor mastery of the topic, as they build up their understanding from their existing knowledge [13]. In short, it shows that teacher plays an important role to ensure that the understanding and knowledge are accurate in helping to master the subject. Hence, this can be achieved through BPBL.

Furthermore, it is found that through an online forum discussion, students can improve their accommodation process where they made changes to their initial understanding that were identified as alternative concepts [39]. Social interaction is an important factor in improving the accommodation process [39] and is highlighted in this study through the use of online forum discussion that allowed students to discuss with group members and the whole class. On the other hand, questions raised by teachers and students during online forum discussions are examples of scaffolding [18] which have helped them to identify and further correct their alternative concepts.

\section{CONCLUSION}

As a conclusion, teachers acts as a mediator in order to stimulate students' thinking in justifying their responses during the implementation of BPBL. Hence, they indirectly help students to identify their alternative concept by asking probing questions. On the other hand, students have analyzed and evaluated other groups' answers in order to identify and correct their alternative concept. Clearly, the implementation of BPBL is found beneficial to overcome the formation of alternative concepts. Since the current study has proven that the implementation of BPBL was able to improve students' mastery on the three representation levels of Chemistry, it is suggested for future researchers to implement BPBL in the other school settings.

\section{Declaration of Confict of Interest}

The author declared no potential conflicts of interest with respect to the research autorships and publications of this article.

\section{REFERENCES}

[1] Dori, Y. J., \& Kaberman, Z. (2011). Assessing high school chemistry students' modeling sub-skills in a computerized molecular modeling learning environment. Instructional Science, 40(1), 69-91.

[2] Jaber, L. Z., \& BouJaoude, S. (2012). A Macro-Micro-Symbolic Teaching to Promote Relational Understanding of Chemical Reactions. International Journal of Science Education, 34(7), 973-998.

[3] Chittleborough, G., \& Treagust, D. (2007). Correct Interpretation of Chemical Diagrams Requires Transforming from One Level of Representation to Another. Research in Science Education, 38(4), 463-482.

[4] Dori, Y., \& Hameiri, M. (2003). Multidimensional analysis system for quantitative chemistry problems: Symbol, macro, micro, and process aspects. Journal of Research in Science Teaching, 40(3), 278-302. 
[5] Johnstone, A. . (1982). Macro and microchemistry. School Science Review, 64, 377-379.

[6] Chittleborough, G. (2014). Learning with Understanding in the Chemistry Classroom. In I. Devetak \& S. A. Glažar (Eds.), Learning with Understanding in the Chemistry Classroom (pp. 25-40). Dordrecht: Springer Netherlands.

[7] Talanquer, V. (2011). Macro, Submicro, and Symbolic: The many faces of the chemistry "triplet." International Journal of Science Education, 33(2), 179-195.

[8] Anuar, M., Nasir, N., Yahaya, N., \& Ibrahim, N. H. (2015). Assessment Of Students ' Mental Models Regarding Hydrogen Chloride Molecule And Its Ionization Properties Among Secondary School, 97(13), 41-49.

[9] Gilbert, J. K., \& Treagust, D. F. (2009). Multiple Representations in Chemical Education. In J. K. Gilbert \& D. Treagust (Eds.), Multiple Representation in Chemical Education (Vol. 4, pp. 333-350). Dordrecht: Springer Netherlands.

[10]Siti Zubaidah Omar, Mohammad Yusof Arshad, Mohd Shafie Rosli, \& Nurbiha A. Shukor. (2016). Students' Understanding On Tranferring Molecular Formula To Structural Formula: The Difficulties And Solutions. In International Conference on Science, Engineering, Management and Social Sciences. Universiti Teknologi Malaysia.

[11]Marchlewicz, S. C., dan Wink, D. J. (2011). Using the Activity Model of Inquiry To Enhance General Chemistry Students' Understanding of Nature of Science. Journal of Chemical Education, 88(8), 1041-1047.

[12]Johari Surif. (2010). Kajian Perbandingan Pemikiran Saintifik Pelajar Malaysia dengan United Kingdom. Doktor Falsafah. Universiti Teknologi Malaysia, Skudai.

[13]Piaget, J. (1976). Piaget's theory (pp. 11-23). Berlin Heidelberg: Springer.

[14]Moust, J. H. C., Berkel, H. J. M. V., dan Schmidt, H. G. (2005). Signs of Erosion: Reflections on Three Decades of Problem-based Learning at Maastricht University. Higher Education, 50(4), 665-683.

[15]Hmelo-Silver, C. (2004). Problem-Based Learning: What and How Do Students Learn? Educational Psychology Review, 16(3), 235-266.

[16]Hmelo-Silver, C., dan Ferrari, M. (1997). The Problem-Based Learning Tutorial: Cultivating Higher Order Thinking Skills. Journal for the Education of the Gifted, 20(4), 401-422.

[17]Barrows, H. S. (1988). The Tutorial Process (Revised Ed.). Sringfield, Ilinois: Southern Illinois University.

[18]Vygotsky, L. . (1930). The Development of Higher Psychological Processes. In Mind and Society. Cambridge: Harvard University Press.

[19]Mohd Mokhzani Ibrahim. (2018). Peranan Guru dan Pelajar dalam Pembelajaran Berasaskan Masalah Mod Campuran. Universiti Pendidikan Sultan Idris.

[20] Suraiya Muhammad, Jamaluddin Harun, Johari Surif, Halim, N. D. A., Omar, S. S., \& Muhammad Umar Khan. (2016). Problem Solving Competency For Open-Ended Problem In Learning Elcetrolysis: A Case Study Of Malaysian Secondary School Chmeistry Students. In 6th IGCESH 2016 International Graduate Conference On Engineering, Science and Humanities (pp. 710-712). Johor Bahru: Universiti Teknologi Malaysia.

[21]Latifah Abdul Raub, Mohammad Yusof Arshad, Nurbiha A. Shukor, \& Mohd Shafie Rosli. (2016). Mastering Higher Order Thinking Skills for Chemistry Literacy. In Nurzatulshima, Haula Hamza, \& Lee Tze Jiun (Eds.), Malaysian Journal of Higher Order Thinking Skills In Education - Promoting Higher Order Thinking Skills in Science Education (2nd ed., pp. 113-123). Johor Bahru: Faculty of education, Universiti Teknologi Malaysia. 
[22]Mohd Mokhzani Ibrahim, Mohammad Yusof Arshad, Mohd Shafie Rosli \& Nurbiha A. Shukor (2016). The Process of Self-Directed Learning in Blended Problem-Based Learning in Chemistry Subject.

Paper presented at International Conference on Education and Higher Order Thinking Skills. Universiti Teknologi Malaysia (UTM).

[23]Mohd Mokhzani Ibrahim, Mohammad Yusof Arshad, \& Mohd Shafie Rosli. (2015). The Need of an Integrated Framework for the Implementation of Blended Problem-Based Learning. International Education Studies, 8(13), 33-40.

[24]Woltering, V., Herrler, A., Spitzer, K., \& Spreckelsen, C. (2009). Blended learning positively affects students' satisfaction and the role of the tutor in the problem-based learning process: results of a mixed-method evaluation. Advances in Health Sciences Education: Theory and Practice, 14(5), 725-38.

[25]Donnelly, R. (2013). The role of the PBL tutor within blended academic development. Innovations in Education and Teaching International, 50(2), 133-143.

[26]Delialioglu, O., dan Yildirim, Z. (2007). Students' Perceptions on Effective Dimensions of Interactive Learning in a Blended Learning Environment. Education Technology \& Society, 10(2), 133-146.

[27]Yin, R. K. (2003). Case Study Research: Design and Method. (K. Wiley, Ed.) (3rd ed.). California: Sage Publications, Inc.

[28]Kementerian Pelajaran Malaysia. (2012). Dasar Pendidikan Kebangsaan (Edisi Keti.). Putrajaya: Bahagian Perancangan dan Penyelidikan Dasar Pendidikan.

[29]Braun, V., \& Clarke, V. (2006). Using thematic analysis in psychology.

[30]Manley, L. M. C. (2012). In Search of Higher-Order Thinking: Examining A Secondary Physics I-WebEnchanced Instructional Design. Capella University.

[31]Jacob, S. M. (2012). Mathematical achievement and critical thinking skills in asynchronous discussion forums. Procedia - Social and Behavioral Sciences, 31(2011), 800-804. doi:10.1016/j.sbspro.2011.12.144

[32]Šum, B., Heričko, M., Pušnik, M., \& Polančič, G. (2011). Factors Affecting Acceptance and Use of Moodle : An Empirical Study Based on TAM, 35, 91-100.

[33]Tan Yin Peen, \& Mohammad Yusof, A. (2013). FILA-MMS Chart in Chemistry PBL Lesson: A Case Study of Its Implementation During Problem Analysis. In The 4th International Research Symposium on Problem-Based Learning (IRSPBL 2013) (pp. 154-162).

[34]Guldberg, K., dan Pilkington, R. (2007). Tutor roles in Facilitating Reflection on Practice Through Online Discussion. Educational Technology \& Society.10 (1), 61-72.

[35]Duit, R., \& Treagust, D. F. (2003). Conceptual Change: A Powerful Framework For Improving Science Teaching and Learning. International Journal of Science Education, 25(6), 671-688.

[36]Abimbola, I. . (1988). The Problem Of Terminology In The Study of Student Conceptions In Science. Science Education, 72(2), 175-184.

[37]Noor Dayana Abdul Halim. (2012). Personalized Learning Environment Based On Cognitive Styles For Mental Model Development In Learning Chemical Bond. Universiti Teknologi Malaysia.

[38]Gedik, N. (2013). Design of a blended learning environment: Considerations and implementation issues. Australasian Journal of Education and Science 29(1), 1-19.

[39]Glasersfeld, V. (1995). Radical Constructivism: A Way of Knowing and Learning. Bristol: Falmer Press, Taylor \& Francis Inc. 
Appendix 1

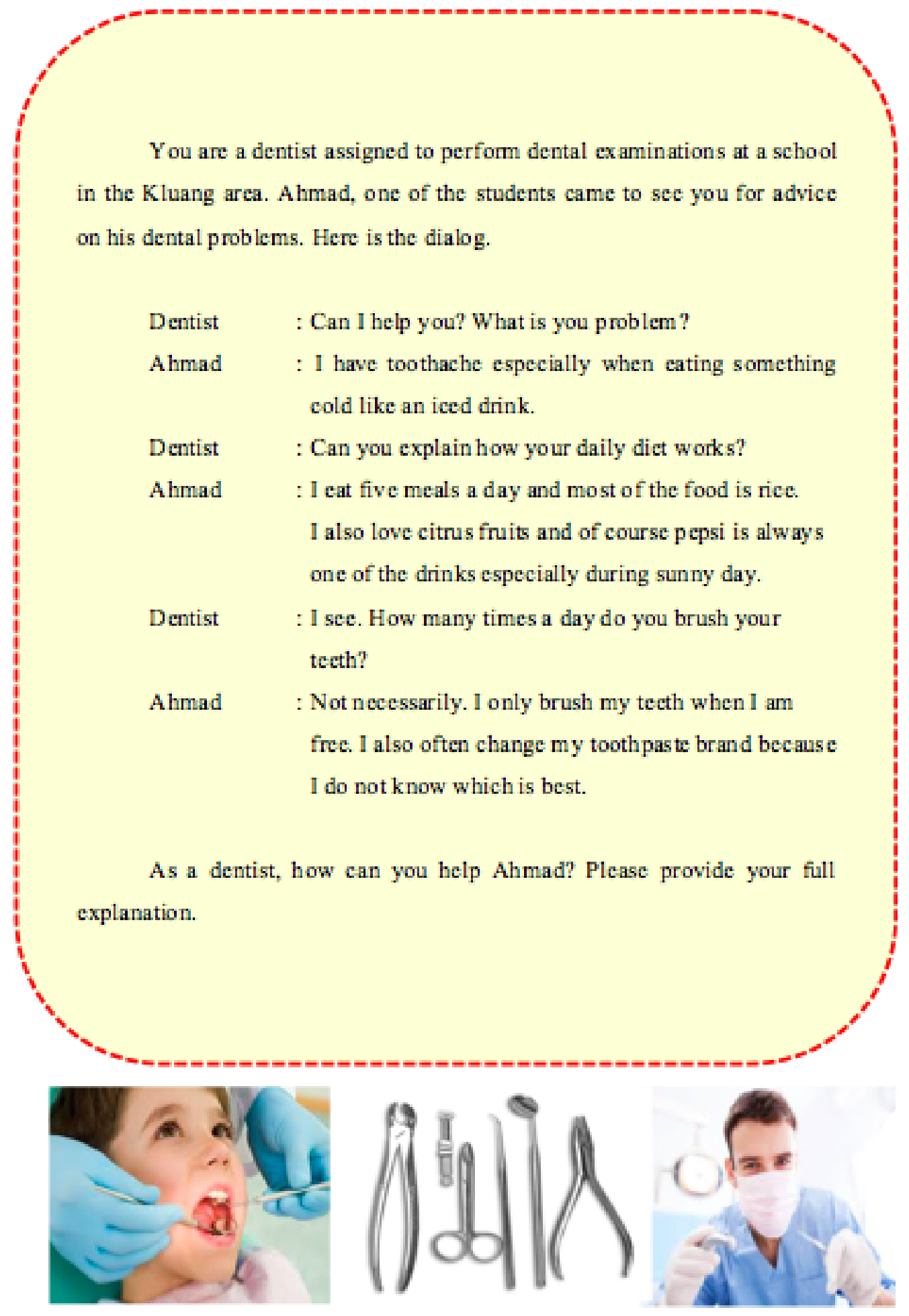

